\title{
EFEKTIFITAS PERATURAN DAERAH KOTA MAKASSAR NOMOR 6 TAHUN 2013 DALAM PEMENUHAN HAK DASAR PENDIDIKAN PENYANDANG DISABILITAS DI KOTA MAKASSAR
}

\section{FIRMAN UMAR, NUR SYARIF RAMADHAN \\ Dosen PPKn FIS UNM}

\begin{abstract}
ABSTRAK: Penelitian ini bertujuan untuk mengetahui: (1) Pemenuhan hak dasar pendidikan bagi Penyandang Disabilitas di Kota Makassar berdasarkan Peraturan Daerah Kota Makassar Nomor 6 Tahun 2013, (2) Kendala yang dihadapi dalam memperoleh hak dasar pendidikan penyandang disabilitas di Kota Makassar, (3) Solusi yang tepat untuk mengatasi kendala yang dihadapi dalam memperoleh hak dasar pendidikan penyandang disabilitas di Kota Makassar. Penelitian ini merupakan penelitian yang menggunakan pendekatan deskriptif kualitatif, yang dimana sumber data primer yang menjadi informannya adalah Siswa Penyandang disabilitas jenjang SMA, Mahasiswa penyandang disabilitas S1, pejabat Dinas Pendidikan Kota Makassar, angota DPRD Kota Makassar, Pengurus Organisasi disabilitas, Pembina LSM dan Orang tua Penyandang disabilitas. Adapun prosedur pengumpulan data yang digunakan adalah wawancara dan dokumentasi. Sedangkan analisis data yang digunakan adalah analisis deskriptif. Hasil penelitian menunjukkan bahwa: (1) Pemerintah Kota Makassar telah mengupayakan terpenuhinya hak dasar pendidikan bagi penyandang disabilitas di Kota Makassar. hal tersebut dibuktikan dengan adanya perda yang didalamnya mengharuskan setiap instansi pendidikan di Kota Makassar untuk memberikan kesempatan bagi penyandang disabilitas untuk memperoleh pendidikan. Efek dari hadirnya perda tersebut ialah pada saat ini penyandang disabilitas telah dapat bersekolah di instansi pendidikan manapun baik di sekolah SLB, Sekolah Reguler dan universitas. (2) masih dijumpai beberapa kendala yang diperoleh penyandang disabilitas dalam mendapatkan hak pendidikannya yakni masih ada instansi pendidikan yang belum mau menerima penyandang disabilitas untuk bersekolah di sekolah regular, sarana dan prasarana pendidikan yang belum aksesibel bagi penyandang disabilitas dan masih ada tenaga pendidik pada sekolah regular yang belum paham dalam menangani peserta didik penyandang disabilitas. (3) untuk mengatasi kendala tersebut, pemerintah harus lebih mensosialisasikan lagi tentang kebijakan yang menjamin pemenuhan hak dasar pendidikan penyandang disabilitas pada instansi pendidikan yang sejauh ini masih belum mau menerima peserta didik penyandang disabilitas. Selain itu, pemerintah harus mengidentifikasi penyandang disabilitas yang bersekolah di sekolah regular, kemudian mengalokasikan anggaran untuk pengadaan sarana dan prasarana serta pelatihan pada tenaga pendidik dalam menangani peserta didik penyandang disabilitas pada sekolah regular maupun universitas.
\end{abstract}

\section{Kata Kunci: Penyandang Disabilitas, Hak-hak Penyandang Disabilitas, Hak Dasar Pendidikan}

\begin{abstract}
This study aims to determine: (1) The fulfillment of basic rights to education for Persons with Disabilities in Makassar based on Local Regulation Makassar City No. 6 of 2013, (2) Obstacles encountered in obtaining the basic right of education of persons with disabilities in the city of Makassar, (3) the right solution to overcome the obstacles encountered in obtaining the basic right of education of persons with disabilities in the city of Makassar. This research is a study that used a qualitative descriptive approach, which is where the primary data source being informers are students with disabilities the high school level, students with disabilities S1, officials of Education Department of Makassar, members of Parliament of Makassar, the Management Organization disabilities, Pembina NGOs and Parents persons with disabilities. The data collection procedures used were interviews and documentation. While the analysis of the data used is descriptive analysis. The results showed that: (1) Makassar City Government has sought the
\end{abstract}


fulfillment of the basic right to education for persons with disabilities in the city of Makassar. it is evidenced with the local regulations require every institution in which education in the city of Makassar to provide opportunities for persons with disabilities to education. The effect of the presence of these regulations is at the moment with disabilities have been able to attend school at any educational institutions both at school SLB, Regular schools and universities. (2) they encountered several obstacles that obtained with disabilities in getting the right to education that is still no educational establishments are not willing to accept persons with disabilities to attend regular schools, educational facilities are not accessible for persons with disabilities and there are educators at regular schools who do not understand in dealing with students with disabilities. (3) to overcome these obstacles, the government should socialize more about the policies that guarantee basic rights of education of persons with disabilities in educational institutions that are still not willing to accept students with disabilities. In addition, the government should identify the persons with disabilities who attend regular school, then allocate the budget for the procurement of infrastructure and training of educators in dealing with students with disabilities in regular schools and universities.

\section{Keywords: Disability Rights of Persons with Disabilities, Basic Rights Education,}

\section{PENDAHULUAN}

Setiap individu dimuka bumi ini memiliki kedudukan, hak, kewajiban dan kesempatan serta peran yang sama dalam segala aspek kehidupan maupun penghidupan seperti individu yang lain. Posisi yang setara menjadi keinginan secara sosiologis dan konstitusional yang menjadi dambaan setiap individu. Pengakuan de facto menjadi penguatan tersendiri yang berlaku di masyarakat untuk mendapatkan perhatian sosial akan dinamika kehidupan kemasyarakatan. Kepastian yang absolut berdampak pada kelangsungan kehidupan yang ideal dan sejahtera yang akan dirasakan oleh semua individu.

Di Indonesia sendiri, landasan bermasyarakat mendapat tempat khusus pada filosofi ketatanegaraan Republik Indonesia sebagaimana terkandung dalam Sila Ke-5, "Keadilan Sosial Bagi Seluruh Rakyat Indonesia". Nilai-nilai yang terkandung pada sila ini menjamin kehidupan dan penghidupan bagi seluruh warga negara akan prinsip keadilan. Dalam Undang-Undang Dasar Negara Republik Indonesia Tahun 1945 Pasal 28 menghormati dan menjunjung tinggi harkat dan martabat manusia tanpa ada pengecualian.

Hak-hak fundamental universal yang tertuang dalam peraturan perundangundangan melahirkan hak dasar yang terbentuk melalui sistematika produk regulasi nasional hingga ke bawah. Mempertegas hal tersebut bahwa dalam Deklarasi Universal Hak-Hak Asasi Manusia (The Universal Declaration Of Human Rights) pasal 29 Ayat 2: Dalam mempergunakan hak-hak dan kebebasan ini, setiap orang hanya dapat dibatasi oleh hal-hal yang ditetapkan hukum yang ditujukan semata-mata untuk menjamin pengakuan dan penghormatan yang layak atas hak-hak dan kebebasan sesamanya serta memenuhi syarat-syarat moral, ketertiban umum dan keselamatan umum yang patut dalam masyarakat demokratis.

Dalam Pasal 1 ayat (3) UndangUndang Dasar Negara Republik Indonesia 1945, Indonesia adalah negara hukum (rechtsstaat):" Negara Indonesia adalah Negara Hukum". Di negara hukum itu sendiri, negara menjamin persamaan di hadapan hukum serta mengakui dan melindungi hak asasi manusia, sehingga semua orang memiliki hak untuk diperlakukan sama di hadapan hukum (equality before the law). Persamaan di hadapan hukum harus disertai dengan persamaan perlakuan (equal treatment). Salah satu bentuk persamaan perlakuan tersebut adalah penyelenggaraan pendidikan disemua tingkat kepada semua lapisan masyarakat sesuai amanat UndangUndang Dasar 1945 tanpa terkecuali kepada penyandang disabilitas.

Pasal 31 ayat (1) Undang-Undang Dasar 1945 diatur bahwa "Setiap warga 
negara berhak mendapat pendidikan". Berdasarkan ketentuan tersebut, negara mengakui hak dasar dibidang pendidikan semua warga negara tanpa pengecualian sedikit pun. Penetapan pasal tersebut mengimplikasikan bahwa penyelengaran persamaan pendidikan bagi penyandang disabilitas merupakan tugas dan wewenang negara baik pada sektor teoritik regulasi maupun implementasi regulasi dalam tatanan berbangsa dan bernegara tanpa diskriminatif. Dasar pertimbangan pada Pasal 28D UUD 1945 yang diatur bahwa: " Setiap orang berhak atas pengakuan, jaminan, perlindungan, dan kepastian hukum yang adil serta perlakuan yang sama di hadapan hukum", penyandang disabilitas memiliki kesamaan hak konstitusional dengan seluruh masyarakat di bidang pendidikan secara khusus.

Salah satu hak dasar yang menjadi fundamental yaitu hak untuk memperoleh pendidikan demi memperoleh kesempatan dan perlakuan yang sama dalam pemerintahan dalam rangka percepatan pembangunan nasional yang bertempat di daerah. Dalam rangka menghadapi tantangan atau persaingan sesuai tuntutan perubahan kehidupan yang bersifat global maka harapan keberlangsungan kesejahteraan masyarakat secara umum dan penyandang disabilitas secara khusus berkolerasi pada tingkat pendidikan yang ditempuh oleh insan tersebut. Kesempatan mengenyam pendidikan sesuai kemampuan dan keinginan tanpa diskriminatif merupakan faktor utama dalam membangun paradigma produktif yang ilmiah bagi kalangan penyandang disabilitas.

Hak dasar pendidikan seyogyanya telah mendapat perlindungan hukum yang pada esensinya sama dengan manusia lainnya. Pendidikan yang dimaksud tentunya berkorelasi dengan kemampuan individu dari penyandang disabilitas tersebut.

Penyandang disabilitas merupakan bagian yang tidak dapat diisolasikan karena terintegrasi di masyarakat Indonesia yang juga memiliki kedudukan, hak, dan kewajiban, dan peran yang sama. Pada kompetensi inilah penyandang disabilitas memerlukan perhatian khusus dikarenakan kewajiban pemerintah dalam menjamin dan melindungi keberlangsungan kesejahteraan hidup warga negaranya. Dalam dunia ketenagakerjaan, persaingan kedudukan dan hak secara adil baru diperoleh dengan kesetaraan tingkat pendidikan yang ditempuh.

Pelaksanaan secara holistik-sosiologis pada regulasi dibidang pendidikan terhadap penyandang disabilitas tidak berdasarkan pada nilai-nilai humanistik yang adil, ideal, dan logis. Ketidakjelasan posisi hukum dalam UU No. 20 tahun 2003, memperlihatkan bahwa substansi hukum yang ada tidak lahir melalui nilai-nilai sosial yang berkembang di masyarakat.

Praktik penegakan hukum dibidang pendidikan di Indonesia masih mencerminkan ketidakadilan antara manusia biasa dengan manusia luar biasa (penyandang disabilitas). Penyandang disabilitas masih mendapatkan perlakuan yang tidak adil di dunia pendidikan seperti masih banyaknya penolakan peserta didik di sekolah reguler, hanya berhak menempuh pendidikan di sekolah khusus (sekolah luar biasa), sulitnya diterima keberadaannya ditengah masyarakat ilmiah, dan berbagai spekulasi lain yang mendiskreditkan keberadaan penyandang disabilitas.

Kurangnya aksesibilitas dibidang pendidikan menyebabkan banyak penyandang disabilitas yang pendidikan formal hanya sampai tahap sekolah dasar. Hal ini berdampak pada kompetensi untuk bersaing dengan yang lain dibidang ketenagakerjaan. Pada tataran pendidikan tinggi pun, aksesibilitas penyandang disabilitas dibidang pendidikan hanya terfokus pada jurusan Pendidikan Luar Biasa dan bersifat terbatas. Ketidaksamaan perlakuan melahirkan diskriminasi sosial dan inkonstitusional dalam segala aspek kehidupan dan penghidupan. Selain itu, sering terjadi penolakan terhadap kehadiran penyandang disabilitas di perguruan tinggi.

Dari jumlah penyandang disabilitas di Kota Makassar pada tahun 2013 sebanyak 2.250, ada sekitar 1.583 orang yang tidak sekolah atau sekitar $70,36 \%$ dan hanya sebanyak 667 orang penyandang disabilitas yang mengenyam bangku pendidikan atau sekitar 29,64\%. Dari 667 orang tersebut, 297 orang duduk di sekolah dasar, 165 orang di 
sekolah menengah pertama, 176 orang di sekolah menengah atas, 4 orang Diploma-1 dan Diploma-2, 3 orang Diploma-3, 19 orang mahasiswa s-1, 1 orang mahasiswa s-2 dan 2 orang mahasiswa s-3.

Angka tidak sekolah bagi penyandang disabilitas sebesar $70.36 \%$. angka tersebut tergolong tinggi sehingga menggambarkan bahwa pemerintah kurang memberikan perhatian khusus bagi penyandang disabilitas. Dampak dari hal tersebut akan berimplikasi pada kualitas hidup penyandang disabilitas secara khusus.

Melihat kondisi tersebut, penulis tertarik untuk mengkaji hak-hak penyandang disabilitas dan lebih dalam dan khusus terkait hak dasar (hak memperoleh pendidikan) yang sebenarnya wajib terealisasi kepada seluruh lapisan masyarakat termasuk penyandang disabilitas itu sendiri. Itulah yang menginspirasi penulis untuk melakukan penelitian mengenai "Efektifitas Peraturan Daerah Kota Makassar Nomor 6 Tahun 2013 Dalam Pemenuhan Hak Dasar Pendidikan Penyandang Disabilitas Di Kota Makassar".

\section{TINJAUAN PUSTAKA}

\section{A. Penyandang Disabilitas}

Di masyarakat umum, kata disabilitas terdengar asing ditelinga sehingga sebagian besar tidak mengetahui dan mengerti makna dibalik kata tersebut. Kata disabilitas merupakan kata yang baru muncul pada tahun 2008 lalu saat pembahasan lanjutan ratifikasi UU No. 19 tahun 2011 tentang Pengesahan Konvensi Hak-Hak Penyandang Disabilitas.

Defenisi Penyandang Disabilitas dapat dilihat pada Convention On The Rights Person With Disabilities di article 1 tentang purpose, yaitu: "Persons with disabilities include those who have long-term physical, mental, intellectual or sensory impairments which in interaction with various barriers may hinder their full and effective participation in society on an equal basis with others.", "Penyandang Disabilitas adalah orang yang memiliki keterbatasan fisik, mental, intelektual, atau sensorik dalam waktu yang lama di mana ketika berhadapan dengan berbagai hambatan, hal ini dapat menghalangi partisipasi efektif mereka dalam masyarakat berdasarkan kesetaraan dengan yang lain.
Sementara itu, dalam Peraturan Daerah Kota Makassar dikatakan: Disabilitas adalah hasil interaksi antara penyandang disabilitas dengan lingkungan yang menghambat partisipasi penuh dalam mencapai kesetaraan kesempatan dalam kehidupan dan penghidupan.. Sedang untuk definisi penyandang disabilitas dalam peraturan daerah Kota Makassar nomor 6 tahun 2013, mengacu pada definisi penyandang disabilitas yang sebelumnya telah dijelaskan pada Convention On The Rights Person With Disabilities. Artinya definisi penyandang disabilitas yang disebutkan dalam perda sama dengan definisi penyandang disabilitas yang ada pada Convention On The Rights Person With Disabilities yakni: Penyandang Disabilitas adalah orang yang memiliki keterbatasan fisik, mental, intelektual, atau sensorik dalam jangka waktu lama di mana ketika berhadapan dengan berbagai hambatan, hal ini dapat menghalangi partisipasi penuh dan efektif mereka dalam masyarakat berdasarkan kesetaraan dengan yang lainnya.

\section{B. Hak-Hak Penyandang Disabilitas}

Hak Asasi Manusia adalah seperangkat hak yang melekat pada hakikat dan keberadaan manusia sebagai makhluk Tuhan Yang Maha Esa dan merupakan anugerah-Nya yang wajib dihormati, dijunjung tinggi dan dilindungi oleh negara, hukum, Pemerintah, dan setiap orang demi kehormatan serta perlindungan harkat dan martabat manusia.

Hak Asasi Manusia

(HAM) merupakan hak-hak yang melekat pada manusia yang mencerminkan martabatnya, yang harus memperoleh jaminan hukum, karena hak-hak hanya dapat efektif jika hakhak itu dapat dilindungi hukum. Melindungi hak-hak dapat terjamin, apabila hak-hak itu merupakan bagian dari hukum, yang memuat prosedur hukum untuk melindungi hak-hak tersebut. Hukum pada dasarnya merupakan pencerminan dari HAM, sehingga hukum itu mengandung keadilan atau tidak, ditentukan oleh HAM yang dikandung dan diatur atau dijamin oleh hukum itu. Hukum tidak lagi dilihat sebagai refleksi kekuasaan sematamata, tetapi juga harus memancarkan perlindungan terhadap hak-hak warga negara. 
Dalam UU No. 19 Tahun 2011, hakhak penyandang Disabilitas yaitu: Setiap penyandang disabilitas harus bebas dari penyiksaan atau perlakuan yang kejam, tidak manusiawi, merendahkan martabat manusia, bebas dari eksploitasi, kekerasan dan perlakuan semena-mena, serta memiliki hak untuk mendapatkan penghormatan atas integritas mental dan fisiknya berdasarkan kesamaan dengan orang lain. Termasuk di dalamnya hak untuk mendapatkan perlindungan dan pelayanan sosial dalam rangka kemandirian, serta dalam keadaan darurat. Berdasarkan undang-undang tersebut, jelas menghindari perlakuan diskriminatif kepada penyandang disabilitas. Hak-hak yang melekat pada diri tak memiliki pembeda akan perlakuan yang diperoleh.

Dipertegas juga dalam Peraturan Daerah no. 6 tahun 2013 pada pasal 1 poin ke-9 yang mengatakan bahwa Kesamaan kesempatan adalah keadaan yang memberikan peluang kepada penyandang disabilitas untuk mendapatkan kesempatan yang sama dalam segala aspek kehidupan dan penghidupan

Dari beberapa referensi di atas, dapat ditarik benang merah mengenai kesamaan kesempatan bagi penyandang disabilitas yaitu bahwa dalam peraturan perundang-undangan menjamin secara konstitusional hak-hak penyandang disabilitas disegala aspek kehidupan dan penghidupan. Hal ini harus menjadi persamaan persepsi kepada keseluruh Stakeholder penyandang disabilitas.

Hal yang menjadi garis bawah yaitu aspek kehidupan dan penghidupan. Yang dimaksud dengan aspek kehidupan dan penghidupan yaitu meliputi antara lain aspek agama, kesehatan, pendidikan, sosial, ketenagakerjaan, ekonomi, pelayanan umum (publik), hukum, budaya, politik, pertahanan keamanan, olahraga, rekreasi, dan informasi.

\section{Hak Dasar Pendidikan}

Menurut Hasnawi Haris, bagi konsep "human Rights" apa yang menjadi hak adalah "what is human?". Fundamental rights meliputi baik "legal rights", maupun "moral rights". Hak-hak tertentu dikatakan "fundamental" bukan karena hak-hak tersebut konstitusional sifatnya artinya ditempatkan dalam konstitusi atau di dalam "basic rules".
Istilah-istilah dalam bahasa Indonesia seperti " hak kodrat" merupakan terjemahan dari "natural right". Namun istilah "hak-hak asasi manusia" dan "hak-hak dasar manusia" itu menimbulkan pertanyaan: apakah istilah tersebut paralel dengan "human right" ataukah "fundamental right"?

Manusia (dalam hak-hak asasi manusia) kiranya paralel dengan "human right" tetapi "asasi atau dasar" kiranya paralel dengan "fundamental right". Dengan demikian, dalam istilah "hak-hak asasi manusia" atau "hak-hak dasar manusia" menurut Hadjon (1987:41) tercakup sekaligus dua istilah secara bersama-sama yaitu "human right" dan "fundamental right".

Menurut Darmawati, Hak Asasi Manusia sebagai hak dasar yang melekat pada diri manusia yang bersifat universal dan abadi, hingga harus dilindungi, dihormati, dan dipertahankan, tidak boleh diabaikan, dikurangi, dan dirampas oleh siapa pun, kecuali oleh UU atau keputusan pengadilan.

Menurut Rustadi (1999:82) dalam Darmawati , Hak Asasi Manusia merupakan dasar bagi hak dan kewajiban lainnya, yang diberikan kesempatan pada manusia agar dapat berkembang sesuai dengan keinginan dan cita-citanya.

Dalam masyarakat yang menghormati hak asasi manusia sesuai dengan the rule of law, terdapat pengakuan terhadap hak dan kewajiban para warga negara. Dengan demikian, hukum akan memperlakukan setiap warga negara sama dengan perlakuan yang diberikan kepada orang lain, siapapun dia dan apapun kekuasaannya.

Berdasarkan pendapat di atas, ditarik kesimpulan bahwa, yang dimaksud dengan hak dasar yaitu hak yang lahir/timbul melalui peraturan perundang-undangan yang secara filosof berasal dari hak asasi manusia secara universal yang dijabarkan secara rinci menurut aspeknya. Posisi peraturan perundang-undangan merupakan penguatan, reposisi, jaminan, perlindungan, dan rekayasa sosial di Indonesia sebagai negara Hukum.

Hak dasar pendidikan merupakan salah satu hak asasi yang lahir dari peraturan perundang-undangan yaitu dimana setiap warga negara dijamin untuk memperoleh hak dasar pendidikan secara adil termasuk 
penyandang disabilitas. Menurut Kansil (2000:46) dalam A. Muh. Harming, bahwa dalam membahas mengenai hak dasar pendidikan, maka implemetasi untuk penyandang disabilitas harus korelasi dengan konsep dari rasa keadilan.

Dalam Peraturan Daerah Kota Makassar No. 6 Tahun 2013, yang secara khusus sebagai payung hukum bagi penyandang disabilitas kususnya di Kota Makassar, terdapat kebijakan tentang perlindungan hak dasar pendidikan bagi penyandang disabilitas yaitu pada Bab IV yang mengatur tentang Kesamaan Kesempatan yakni pada Pasal 10 bagian a yang diatur bahwa:

Pasal 10

Setiap penyandang disabilitas mempunyai kesamaan kesempatan dalam bidang :

a. Pendidikan;

b. Kesehatan;

c. Olahraga;

d. Seni Budaya;

e. Ketenagakerjaan;

f. Berusaha;

g. Pelayanan Umum;

h. Politik;

i. Bantuan Hukum; dan

j. Informasi.

Pada Pasal 10, diatur kesamaan kesempatan kepada penyandang disabilitas dengan warga negara biasa lainnya dalam hal pendidikan mulai pada satuan, jalur, jenis, dan jenjang pendidikan. Kepastian memperoleh pendidikan bagi penyandang disabilitas dapat juga dilihat dalam Perda Kota Makassar No. 6 tahun 2013 pada Pasal 11 dan pasal 12, yang diatur bahwa:

\section{Pasal 11}

(1) Setiap penyelenggara pendidikan memberikan kesempatan dan perlakuan yang sama dalam pendidikan bagi penyandang disabilitas sesuai jenis, derajat kedisabilitasan, dan kemampuannya;

(2) Pendidikan bagi penyandang disabilitas sebagaimana dimaksud pada ayat (1), dapat berbentuk kelas terpadu atau inklusi pada satuan pendidikan umum, satuan pendidikan kejuruan, dan pendidikan keagamaan;

(3) Penyelenggaraan kelas terpadu atau inklusi sebagaimana dimaksud pada ayat (1) dapat melibatkan satu atau beberapa jenis dan/atau derajat kedisabilitasan peserta didik;

(4) Penyandang disabilitas yang karena jenis dan derajat kedisabilitasannya tidak dapat mengikuti pendidikan seperti tercantum pada ayat (3), maka memiliki kesempatan dan hak memperoleh pendidikan khusus.

Pasal 12

(1) Penyelenggara pendidikan sebagaimana dimaksud dalam Pasal 11 menyediakan secara bertahap sesuai kemampuan keuangan daerah:

a. Prasarana dan sarana sesuai jenis dan derajat kedisabilitasan peserta didik;

b. guru dan pembimbing khusus yang memiliki kompetensi dan sertifikasi di bidangnya; dan

c. program kegiatan pembelajaran untuk dikembangkan menjadi kelas inklusi.

(2) Dalam hal penyandang disabilitas yang karena jenis dan/atau derajat kedisabilitasannya tidak dapat mengikuti kelas terpadu atau inkusi sebagaimana dimaksud dalam Pasal 11, ditempatkan pada sekolah luar biasa (SLB) yang ada sesuai dengan standar pendidikan.

Hak dasar pendidikan seyogyanya telah mendapat perlindungan hukum yang pada esensinya sama dengan manusia lainnya. Pendidikan yang dimaksud tentunya berkorelasi dengan kemampuan individu dari penyandang disabilitas tersebut. Sebagai penguat teori hukum, penelitian ini juga merujuk dalam UU. 20 Tahun 2003 tentang Sistem Pendidikan Nasional dan beberapa peraturan perundang-undangan, dimana juga 
terdapat beberapa ketentuan yang mengatur tentang posisi penyandang disabilitas akan hak dasar pendidikannya dikategorikan pendidikan khusus. Hal ini dapat dilihat pada UU No. 20 Tahun 2003 Pasal 5 ayat 2 dan Pasal 32 ayat 1 diatur bahwa;

\section{Efektifitas}

Kata efektif berasal dari bahasa inggris yaitu effective yang berarti berhasil, atau sesuatu yang dilakukan berhasil dengan baik. Kamus ilmiah popular mendefinisikan efektivitas sebagai ketepatan penggunaan, hasil guna atau menunjang tujuan. Efektivitas dapat didefinisikan dengan empat hal yang menggambarkan tentang efektivitas, yaitu :

1. Mengerjakan hal-hal yang benar, dimana sesuai dengan yang seharusnya diselesaikan sesuai dengan rencana dan aturannya.

2. Mencapai tingkat diatas pesaing, dimana mampu menjadi yang terbaik dengan lawan yang lain sebagai yang terbaik.

3. Membawa hasil, dimana apa yang telah dikerjakan mampu memberi hasil yang bermanfaat.

4. Menangani tantangan masa depan .

Efektivitas pada dasarnya mengacu pada sebuah keberhasilan atau pencapaian tujuan. Efektivitas merupakan salah satu dimensi dari produktivitas, yaitu mengarah kepada pencapaian untuk kerja yang maksimal, yaitu pencapaian target yang berkaitan dengan kualitas, kuantitas dan waktu.

Dari uraian diatas terlihat bahwa efektivitas lebih menekankan pada aspek tujuan yang telah ditetapkan, dengan demikian efektifitas pada hakikatnya berorientasi pada pencapaian tujuan atau sasaran yang telah ditentukan sebelumnya. Jadi apabila telah dicapai baru dikatakan efektif.

\section{METODE PENELITIAN}

Penelitian ini menggunakan
pendekatan deskriptif-kualitatif dimaksudkan untuk memberikan gambaran dan penjelasan mengenai pelaksanaan Perda Kota Makassar No. 6 Tahun 2013 Tentang Pemenuhan Hak-hak Penyandang Disabilitas dalam kaitannya dengan keefektifan hak-hak yang diterima oleh penyandang disabilitas di
Kota Makassar. Penelitian ini merupakan penelitian yang bersifat normatif dan ditunjang dengan penelitian yang bersifat empiris yaitu penelitian difokuskan dalam mengkaji penerapan nilai-nilai dan norma dalam hukum, disertai teori-teori dan asasasas hukum yang berkaitan dengan permasalahan yang diteliti (Ibrahim. 2006).

Jenis penelitian yang digunakan dalam penelitian ini adalah jenis penelitian fenomenologi. Penelitian fenomenologi mencoba menjelaskan atau mengungkap makna konsep atau fenomena pengalaman yang didasari oleh kesadaran yang terjadi pada beberapa individu. Penelitian ini dilakukan dalam situasi yang alami, sehingga tidak ada batasan dalam memaknai atau memahami fenomena yang dikaji. Menurut Creswell (1998), Pendekatan fenomenologi menunda semua penilaian tentang sikap yang alami sampai ditemukan dasar tertentu. Penundaan ini biasa disebut epoche (jangka waktu). Konsep epoche adalah membedakan wilayah data (subjek) dengan interpretasi peneliti. Konsep epoche menjadi pusat dimana peneliti menyusun dan mengelompokkan dugaan awal tentang fenomena untuk mengerti tentang apa yang dikatakan oleh responden. Alasan peneliti menerapkan jenis pendekatan kualitatiffenomenologi dalam penelitian ini adalah untuk menemukan dan memahami apa yang tersembunyi dibalik dinamika sosiologisyuridis penyandang disabilitas sebagai persoalan sosial yang ada di Kota Makassar. Adapun lokasi penelitian ini dilaksanakan di Kota Makassar dengan akses dibidang ekonomi, sosial, pendidikan, pelayanan publik dan kesehatan kelihatan jelas dalam roda pemerintahan. Kota Makassar merupakan daerah persinggahan terpadat di kawasan Indonesia Timur. Selain itu, Kota Makassar juga merupakan satusatunya wilayah di Sulawesi Selatan yang telah memiliki peraturan daerah yang khusus mengatur tentang penyandang disabilitas. Hal tersebut juga dapat memberikan gambaran kehidupan penyandang disabilitas dalam memperoleh aksesibilitas dibidang pendidikan secara khusus.

Sumber data dalam penelitian ini adalah: 
1. Data primer bersumber dari subjek penelitian yakni penyandang disabilitas, Pejabat Dinas Pendidikan Kota Makassar, Anggota DPRD Kota Makassar, Pembina LSM, Organisasi Penyandang disabilitas dan orang tua penyandang disabilitas. Dalam menentukan subjek penelitian, peneliti menggunakan tekhnik purporsive sampling.

2. Data sekunder bersumber dari : penelahan studi kepustakaan ( buku dan sebagainya) yang relevan dengan data yang dibutuhkan.

Untuk mendapatkan informasi tentang data yang dibutuhkan dalam penelitian ini, teknik yang digunakan adalah observasi, wawancara dan dokumentasi.Observasi adalah teknik yang dilakukan untuk mengamati kegiatan dan hasil pelaksanaan pemenuhan hak pendidikan bagi penyandang disabilitas. Observasi yang dilakukan dibeberapa tempat seperti sekolah, sekretariat, dan lain-lain. Observasi ini dilakukan dalam rangka perolehan data mengenai lokasi penyandang disabilitas demi gambaran awal. Wawancara digunakan sebagai teknik pengumpulan data dengan melakukan tanya jawab kepada pihak-pihak yang terkait dengan penyandang disabilitas. Wawancara ini diperlukan dalam rangka menjawab rumusan masalah dalam penelitian ini. Dokumentasi merupakan teknik pengumpulan data dengan cata mencatat secara langsung dari dokumen yang berkaitan dengan penelitian. Dokumentasi ini diperlukan sebagai bukti lapangan penelitian.

Dalam penelitian kualitatif, suatu data dikatakan valid apabila tidak terdapat perbedaan antara apa yang dilaporkan oleh peneliti dengan apa yang sesungguhnya terjadi dilapangan atau objek yang diteliti. Sedang realibilitas dalam penelitian kualitatif bergantung pada realitas yang sifatnya majemuk/ganda, dinamis/selalu berubah, sehingga tidak ada yang konsisten dan berulang seperti semula. Artinya, data yang dihasilkan peneliti tidak konsisten/tetap sehingga dapat berubah sewaktu-waktu.

Dalam penelitian ini digunakan teknik triangulasi untuk memeriksa keabsahan data yang diperoleh dilapangan. Triangulasi pada hakikatnya merupakan pendekatan multimetode yang dilakukan peneliti pada saat mengumpulkan dan menganalisis data. Ide dasarnya adalah bahwa fenomena yang diteliti dapat dipahami dengan baik sehingga diperoleh kebenaran tingkat tinggi jika didekati dari berbagai sudut pandang. Memotret fenomena tunggal dari sudut pandang yang berbeda-beda akan memungkinkan diperoleh tingkat kebenaran yang handal. Karena itu, triangulasi ialah usaha mengecek kebenaran data atau informasi yang diperoleh peneliti dari berbagai sudut pandang yang berbeda dengan cara mengurangi sebanyak mungkin perbedaan yang terjadi pada saat pengumpulan dan analisis data.

Terdapat tiga macam triangulasi, yaitu triangulasi waktu, triangulasi teknik, dan triangulasi sumber. Dalam penelitian ini, triangulasi yang digunakan adalah triangulasi sumber. Triangulasi sumber yang berbeda yaitu wawancara siswa disabilitas yang saat ini bersekolah di jenjang sma dan perguruan tinggi, kemudian dilihat apakah hasil kedua jenis wawancara tersebut konsisten pada data yang sama. Selain itu, peneliti juga memiliki informan penelitian yang diambil dari pejabat dinas pendidikan Kota Makassar, Pembina lsm, anggota dprd Kota Makassar, organisasi penyandang disabilitas dan orang tua penyandang disabilitas.

Menurut miles dan huberman, menyatakan bahwa aktifitas dalam analisis data kualitatif dilakukan secara interaktif dan berlangsung secara terus menerus sampai tuntas, sehingga datanya sudah jenuh. Langkah-langkah dalam analisis data adalah:

1. Reduksi data (data reduction) yaitu kegiatan yang mengacu pada proses merangkum, memilih hal-hal pokok, memfokuskan pada hal-hal yang penting, dicari pola dan temanya. Dalam mereduksi data, setiap peneliti akan dipandu oleh tujuan yang akan dicapainya. Tujuan utama dalam penelitian kualitatif adalah pada temuan. Oleh karena itu, kalau peneliti dalam melakukan penelitian, menemikan segala sesuatu yang diangap asing, tidak dikenal, belum memiliki pola, maka hal itulah yang 
harus dijadikan perhatian bagi peneliti dalam melakukan suatu reduksi data.

2. Pemaparan data (data display) yang meliputi pengklasifikasian dan identifikasi data, yaitu menuliskan kumpulan data yang terorganisir dan terkategori sehingga memungkinkan untuk menarik kesimpulan dari data tersebut.

3. Menarik kesimpulan (conclusion) dari hasil analisis data yang telah dikumpulkan dan memverifikasi kesimpulan tersebut.

Setelah data yang diperlukan seluruhnya telah diperoleh, maka langkah selanjutnya adalah data diolah sedemikian rupa. Data hasil penelitian dianalisis secara deskriptif. Hasil wawancara dianalisis secara kualitatif. Dalam rangka mengetahui hak dasar pendidikan penyandang disabilitas berdasarkan Perda Kota Makassar No. 6 tahun 2013 dan kendala-kendala dalam pemenuhan hak dasar pendidikan bagi penyandang disabilitas, lebih lanjut diinterpretasikan secara deskriptif dimana capaian pada proses akhir diharapkan dapat diperoleh secara kesimpulan yang bersifat umum sebagai jawaban terhadap permasalahan yang diteliti.

\section{PEMBAHASAN}

1. Pemenuhan Hak Dasar Pendidikan Penyandang Disabilitas Di Kota Makassar

Kesamaan kesempatan adalah keadaan yang memberikan peluang kepada penyandang disabilitas untuk mendapatkan kesempatan yang sama dalam segala aspek kehidupan dan penghidupan. Salah satu aspek yang sangat penting dalam hal kehidupan dan penghidupan ialah hak memperoleh pendidikan. Sebelum peraturan daerah Kota Makassar nomor 6 tahun 2013tentang pemenuhan hak-hak penyandang disabilitas disahkan, sering terjadi diskriminasi terhadap penyandang disabilitas dalam hal pendidikan. Saat itu, kebanyakan instansi pendidikan di Kota Makassar menolak keberadaan penyandang disabilitas. Mereka beranggapan bahwa seorang penyandang disabilitas tidak dapat berbaur dengan masyarakat umum dan hanya dapat bersekolah di sekolah luar biasa.

Pandangan yang keliru tersebut tentunya bertentangan dengan undang-undang dasar 1945 yang menjamin terpenuhinya kebutuhan akan pendidikan bagi seluruh rakyat Indonesia. Penyandang disabilitas juga merupakan warga Negara yang memiliki kedudukan dan hak yang sama dengan masyarakat pada umumnya.

Adanya diskriminasi yang dialami oleh penyandang disabilitas di Kota Makassar tersebut membuat beberapa kalangan memperjuangkan terpenuhinya hak pendidikan bagi penyandang disabilitas. Organisasi disabilitas bersama beberapa LSM berjuang dan mengadvokasi pemerintah Kota Makassar agar mau mengeluarkan kebijakan yang dapat menjamin terpenuhinya hak dasar pendidikan bagi penyandang disabilitas di Kota Makassar.

Akhirnya, pada 2013, pemerintah Kota Makassar mengeluarkan peraturan daerah nomor 6 tahun 2013 tentang pemenuhan hak-hak penyandang disabilitas. Selain itu, waliKota Makassar juga mengeluarkan Perwali Nomor 90 tahun 2013 Tentang Pendidikan Inklusif.

Kedua kebijakan tersebut berdampak positif dalam memberikan kesempatan pada penyandang disabilitas untuk mengenyam pendidikan. Sejak kedua regulasi tersebut dikeluarkan, jumlah sekolah luar biasa semakin bertambah. Selain di SLB, penyandang disabilitas yang mampu bersekolah di sekolah regular pun telah diberikan kesempatan lewat adanya kebijakan pendidikan inklusif.

Pendidikan Inklusif merupakan system penyelenggaraan pendidikan yang memberikan kesempatan kepada semua peserta didik berkebutuhan khusus yang memiliki kelainan dan memiliki potensi kecerdasan dan/atau bakat istimewa untuk mengikuti pendidikan dan pembelajaran dalam satu lingkungan pendidikan secara bersama-sama dengan peserta didik pada umumnya di sekolah regular. Semenjak pemerintah Kota Makassar Mengeluarkan kebijakan tentang Pendidikan Inklusif, kesempatan bagi penyandang disabilitas untuk bersekolah di sekolah regular semakin terbuka. Meskipun pada saat ini penyandang disabilitas yang bersekolah di SLB masih jauh lebih besar jika dibandingkan dengan 
penyandang disabilitas yang bersekolah di sekolah regular.

\section{Kendala Dalam Pemenuhan Hak Dasar Penyandang Disabilitas Di Kota Makassar.}

Meskipun pemerintah Kota Makassar telah memberikan kesempataan yang luas bagi penyandang disabilitas dalam memperoleh pendidikan, ternyata pada proses yang terjadi kemudian, masih ada saja beberapa kendala yang menjadi hambatan. Kendala-kendala tersebut diantaranya adalah masih adanya instansi pendidikan yang menolak keberadaan penyandang disabilitas, sarana dan prasarana yang kurang aksesibel bagi penyandang disabilitas,dan masih banyak tenaga pendidik di sekolah regular dan universitas yang masih belum mengetahui tentang dunia kedisabilitasan.

Kendala yang pertama adalah masalah kesempatan. Ternyata masih ada sekolah regular di Kota Makassar yang menolak keberadaan penyandang disabilitas. Sedangkan pada universitas, penyandang disabilitas terkadang dipandang hanya bias berkuliah pada jurusan pendidikan luar biasa. Ini tentunya bertentangan dengan apa yang diatur dalam perda nomor 6 tahun 2013 pasal 11 ayat 1 yang mengharuskan Setiap penyelenggara pendidikan untuk memberikan kesempatan dan perlakuan yang sama dalam pendidikan bagi penyandang disabilitas sesuai jenis, derajat kedisabilitasan, dan kemampuannya.

Kendala selanjutnya adalah persoalan sarana dan prasarana pendidikan yang ada di sekolah regular dan universitas masih belum aksesibel bagi penyandang disabilitas. Sarana dan prasarana yang dimaksud seperti area lingkungan dan bangunan. Bahkan pada jurusan Pendidikan Luar Biasa Universitas Negeri Makassar, jurusan yang paling dianggap aksesibel bagi penyandang disabilitas, pun belum dapat dikatakan aksesibel jika mengacu pada area lingkungan kampus serta bangunan gedung perkuliahan.

Selain SLB, satu-satunya bangunan milik instansi pendidikan di Kota Makassar yang dapat dikatakan sedikit aksesibel bagi penyandang disabilitas adalah gedung menara phinisi, Universitas Negeri Makassar. Gedung ini sedikit aksesibel bagi penyandang disabilitas netra dan penyandang disabilitas daksa. Bagi pengguna kursi roda, telah disediakan area khusus untuk memasuki gedung. sedangkan bagi penyandang disabilitas netra, telah disediakan huruf Braille pada tombol lif.

Permasalahan berikutnya yang masih berhubungan dengan sarana dan prasarana pendidikan ialah perpustakaan. Di Kota Makassar, hamper semua perpustakaan umum maupun perpustakaan milik instansi pendidikan belum dapat diakses oleh penyandang disabilitas, khususnya penyandang disabilitas netra. Biasanya, untuk mengakses buku-buku yang ada diperpustakaan, penyandang disabilitas netra perlu mendapatkan bantuan dari petugas perpustakaan ataupun dari mereka yang non disabilitas.

Kendala berikutnya adalah tenaga pendidik. Di sekolah regular maupun di universitas, masih banyak tenaga pendidik yang masih belum mengetahui bagaimana menangani seorang penyandang disabilitas. Untuk tingkat SMA, kendala diperoleh pada guru mata pelajaran yang memerlukan kemampuan berhitung seperti pada mata pelajaran Matematika, Fisika, Kimia dan Ekonomi. Umumnya yang mengalami kendala ini adalah penyandang disabilitas netra karena guru pada mata pelajaran tersebut menjelaskan secara visual atau dengan kata lain sang guru tak menyebutkan secara menyeluruh rumus maupun angka yang ada di papan tulis. Sedangkan pada universitas, kendala umumnya diperoleh oleh penyandang disabilitas rungu yang kesulitan mengikuti proses perkuliahan karena dosen tidak mengerti bahasa isyarat.

\section{Solusi Dalam Mengatasi Kendala Pemenuhan Hak Dasar Pendidikan Penyandang Disabilitas Di Kota Makassar}

Sebelumnya, telah dijelaskan beberapa kendala yang diperoleh dalam pemenuhan hak dasar pendidikan penyandang disabilitas. Tentunya, dibutuhkan solusi untuk mengatasi kendala-kendala tersebut, agar kedepannya, pemberian hak dasar pendidikan bagi penyandang disabilitas di Kota Makassar bisa jauh lebih efektif. Sebagaimana dijelaskan sebelumnya, tiga kendala utama yang banyak 
diperoleh yakni, masih adanya instansi pendidikan yang tak menerima keberadaan penyandang disabilitas, sarana dan prasarana yang tidak aksesibel dan tenaga pendidik yang belum memahami penyandang disabilitas.

Untuk mengatasi kendala yang pertama, yakni instansi pendidikan yang belum mau menerima penyandang disabilitas untuk bersekolah maupun berkuliah, seharusnya pemerintah Kota Makassar melakukan sosialisasi tentang disabilitas. Sejauh ini, pemerintah Kota memang telah mengeluarkan kebijakan yang menjamin terpenuhinya pemenuhan hak pendidikan penyandang disabilitas. Namun, masih sangat kurang instansi pendidikan yang mengetahui akan kebijakan tersebut. Pemerintah yang dalam hal ini dinas pendidikan harus melakukan semacam sosialisasi yang berkelanjutan pada tiap-tiap instansi pendidikan di Kota Makassar. Sosialisasi tersebut bisa dilakukan bekerjasama dengan organisasi penyandang disabilitas maupun LSM yang peduli terhadap penyandang disabilitas. Dengan demikian, diharapkan kedepannya tidak ada lagi penolakan yang dialami seorang penyandang disabilitas ketika akan melanjutkan pendidikannya di sekolah regular maupun pada universitas.

Kendala selanjutnya ialah pada tenaga pendidik. Dimana, pada sekolah regular maupun universitas, masih banyak tenaga pendidik yang tidak mengetahui bagaimana menangani seorang penyandang disabilitas. Sejauh ini, sekolah penyelanggara pendidikan inklusif di Kota Makassar, bergantung pada guru SLB dalam hal memberikan bimbingan pada guru di sekolah inklusif. Ini tentunya sangat tidak efektif, mengingat guru SLB juga memiliki tanggung jawab yang harus dikerjakan di sekolahnya masing-masing. Agar tenaga pendidik di sekolah inklusif tidak tergantung lagi pada guru slb, pemerintah Kota seharusnya menyiapkan dana untuk meningkatkan skil dan kemampuan guru-guru di sekolah penyelenggara pendidikan inklusif khususnya dalam memahami siswa penyandang disabilitas.

Sebenarnya, pada tahun 2014, Dinas Pendidikan Kota sudah mengeluarkan anggaran untuk menyediakan guru pembimbing khusus. Nah, yang menjadi guru pembimbing khusus pada saat itu diambil dari guru SLB. Namun, hal tersebut tidak efektif karena terkadang, guru pembimbing khusus tidak dapat melaksanakan kewajibannya di sekolah inklusif diakibatkan karena mereka juga memiliki tanggung jawab di sekolah SLB. Maka dari itu, untuk kedepannya, yang harus menjadi guru pembimbing khusus tersebut harus berasal dari sekolah inklusif itu sendiri yang memiliki siswa penyandang disabilitas. Itu tentunya jauh lebih bermanfaat karena jumlah pendidik yang paham tentang penyandang disabilitas akan jauh lebih bertamba.

Sedangkan dalam hal sarana dan prasarana, hambatan utamanya juga dalam hal anggaran. Pemerintah Kota belum mengalokasikan anggaran untuk menyediakan sarana dan prasarana yang akses bagi penyandang disabilitas. Maka dari itu, pemerintah Kota Makassar seharusnya mengidentifikasi penyandang disabilitas ataupun sekolah regular yang memiliki siswa penyandang disabilitas. Tidak semua sekolah regular di Kota Makassar memiliki siswa penyandang disabilitas. Mengapa sarana dan prasarana tersebut sulit untuk diadakan, karena pemerintah ingin menyiapkan sarana dan prasarana pada semua sekolah regular. Ini tentunya tidak memungkinkan dan juga tidak efektif. Seharusnya pemerintah focus dalam mempersiapkan sarana dan prasarana yang aksesibel pada instansi pendidikan yang memiliki peserta didik penyandang disabilitas.

\section{PENUTUP}

\section{Kesimpulan}

Adapun kesimpulan dari penelitian ini ialah: (1) Pemerintah Kota Makassar telah mengupayakan terpenuhinya hak dasar pendidikan bagi penyandang disabilitas di Kota Makassar. hal tersebut dibuktikan dengan adanya perda yang didalamnya mengharuskan setiap instansi pendidikan di Kota Makassar untuk memberikan kesempatan bagi penyandang disabilitas untuk memperoleh pendidikan. (2) Kendala yang diperoleh dalam pemenuhan hak dasar pendidikan penyandang disabilitas ialah masih ada instansi pendidikan yang belum mau menerima penyandang disabilitas untuk 
bersekolah di sekolah regular, sarana dan prasarana pendidikan yang belum aksesibel bagi penyandang disabilitas dan masih ada tenaga pendidik pada sekolah regular yang belum paham dalam menangani peserta didik penyandang disabilitas. (3) Solusi yang harus dilakukan untuk mengatasi kendala dalam pemenuhan hak dasar pendidikan bagi penyandang disabilitas ialah, pemerintah perlu mensosialisasikan tentang kebijakan yang menjamin pemenuhan hak dasar pendidikan penyandang disabilitas pada instansi pendidikan yang saat ini masih belum mau menerima peserta didik penyandang disabilitas. Selain itu, pemerintah harus mengidentifikasi penyandang disabilitas yang bersekolah di sekolah regular, kemudian mengalokasikan anggaran untuk pengadaan sarana dan prasarana serta pelatihan pada tenaga pendidik dalam menangani peserta didik penyandang disabilitas pada sekolah regular maupun universitas.

\section{Saran}

Adapun saran dalam penelitian ini diantaranya: (1) bagi penyandang disabilitas, diharapkan untuk terus berjuang dalam pendidikan, jangan pernah takut untuk bersekolah di sekolah regular, gunakanlah kesempatan yang telah diberikan oleh pemerintah Kota Makassar dengan sebaikbaiknya. Tunjukkanlah pada mereka jika penyandang disabilitas juga mampu meraih kesuksesan dalam pendidikan. (2) Bagi organisasi disabilitas, diharapkan agar tak pernah lelah dalam mengadvokasi pemerintah maupun masyarakat pada umumnya dalam pemenuhan hak-hak dasar penyandang disabilitas. (3) Bagi pemerintah Kota Makassar, diharapkan agar melakukan evaluasi tentang pelaksanaan pendidikan inklusif di Kota Makassar. evaluasi ini penting, karena kita bisa membenahi apa saja yang perlu ditingkatkan dalam pelaksanaan pendidikan inklusif tersebut.

\section{DAFTAR PUSTAKA}

$\begin{array}{lcr}\text { Arikunto, } & \text { Suharsimi. } & 2005 . \\ \text { Manajemen } & \text { Penelitian. } & \text { Jakarta: } \\ \text { Rineka Cipta } & & \end{array}$

Creswell, J. W. 1998. Qualitatif Inquiry and Research Design. Sage Publications, Inc: California.

Darmawati. 2010. Pelanggaran Hak Asasi Manusia Oleh Anggota POLRI dalam Kaitannya dengan Tindakan Upaya Paksa (violation of The Human Rights by The Police Members In Relations to the Pressing Action; Tesis. Program Pascasarjana Universitas Negeri Makassar: Tidak Diterbitkan

Gultom, Maidin. 2014. Perlindungan Hukum Terhadap Anak dalam Sistem Peradilan Pidana Anak di Indonesia. Bandung: Refika Aditama

Haris, Hasnawi. 2006. Demokrasi dan Hak Asasi Manusia di Indonesia "Studi Kritis dengan pendekatan Konseptual dan Statuta. Makassar: Badan Penerbit Universitas Negeri Makassar

Harming, Andi Muh. Harming. 2010. Perlindungan Hukum terhadap Anak Jalanan di Kota Makassar (Law Protection Towards Street Chidren In Makassar City); Tesis. Program Pascasarjana Universitas Negeri Makassar: Tidak diterbitkan

Kaelang HD, M.A. 2005. Islam dan Aspek-aspek Kemasyarakatan Edisi Kedua. Jakarta: Bumi Aksara

Manullang, E. Fernando M. 2007. Menggapai Hukum berkeadilan, Tinjauan Hukum Kodrat dan Antinomi Nilai. Jakarta: Kompas

Maududi, Maulana Abul A'la. 2008. Hak-Hak Asasi Manusia dalam Islam. Jakarta: Bumi Aksara

Moleong J. dan Lexy. 2008. Metodologi Penelitian Kualitatif. Bandung: PT. Remaja Rosdakarya 
Saifullah. 2007. Refleksi Sosiologi

Hukum. Bandung: Refika Aditama

Sugiyono. 2008. Memahami

Penelitian Kualitatif. Bandung:

Alfabeta.

Tahir, Heri. 2010. Proses Hukum Yang

Adil Dalam Sistem Peradilan Pidana

Di Indonesia. Yogyakarta: LaksBang

PRESSindo

Utsman, Sabian. 2010. Dasar-Dasar Sosiologi Hukum, Memaknai Dialog Antara Hukum dan Masyarakat. Yogyakarta: Pustaka Pelajar

Waluyo, Bambang. 2008. Penelitian Hukum dalam Praktek. Jakarta: Sinar Grafika

Winarta, Frans Hendra. 2009. Pro

Bono Publico, Hak Konstitusional

Fakir Miskin Untuk Memperoleh

Bantuan Hukum. Jakarta: Gramedia

Undang-Undang Dasar Negara Republik Indonesia Tahun 1945

Undang-Undang Negara Republik Indonesia Nomor 4 Tahun 1997 Tentang Penyandang Cacat, LN RI Tahun 1997 No. 9, TLN No. 3702

Undang-Undang Republik Indonesia Nomor 39 Tahun 1999 Tentang Hak Asasi Manusia, LN RI Tahun 1999 No. 165, TLN No. 3886

Undang-Undang Republik Indonesia Nomor 20 Tahun 2003 Tentang Sistem Pendidikan Nasional, TLN RI No. 4301

Undang-Undang Republik Indonesia Nomor 19 tahun 2011 Tentang Pengesahan Convention On The Rights Of Person With Disabilities (Konvensi Mengenai Hak-Hak Penyandang Disabilitas), LN RI Tahun 2011 No. 107, TLN 5251
Undang-Undang Republik Indonesia Nomor 8 Tahun 2016 Tentang Penyandang Disabilitas, TLN RI No. 5871

Peraturan Daerah Kota Makassar Nomor 6 Tahun 2013 Tentang Pemenuhan Hak-Hak Dasar Penyandang Disabilitas

Draft Convention On The Rights Of Person With Disabilities

Hilmiyah, 2012. "Aksesibilitas Karangan Pemerintah". Identitas. Edisi 783 Tahun XXXVIII. Desember. Hal. 10 